\title{
An analysis of prehospital care for victims of accidents and violence in Recife, Brazil
}

\section{Análisis de la atención prehospitalaria proporcionada a las víctimas de accidentes y violencia en Recife, Brasil}

\author{
Maria Luiza Carvalho de Lima, Edinilsa Ramos de Souza, Suely Ferreira Deslandes, \\ Alice Kelly and Amanda Priscila de Santana Cabral \\ Department of Studies in Collective Health, Aggeu Magalhães Research Center. FIOCRUZ. \\ Department of Social Medicine, Federal University of Pernambuco. Recife, Brazil. \\ luiza@cpqam.fiocruz.br
}

Received $22^{\text {th }}$ April 2009/Sent for Modification $1^{\text {th }}$ November 2009/Accepted $12^{\text {th }}$ December 2009

\begin{abstract}
Objectives This study was aimed at carrying out a situational diagnosis of the prehospital healthcare network for victims of accidents and violence in Recife, Brazil.

Methods National policy for reducing accident- and violence-related morbidity and mortality was used as reference. Questionnaires were applied and half-structured interviews conducted with managers and healthworkers from thirteen prehospital fixed units and one mobile unit.

Results Children, adolescents and females predominantly sought attention; there were few preventative actions, little social coverage and deficient referral, counterreferral and communication with other sectors. A lack of equipment and basic materials, insufficient multidisciplinary teams and the need for ongoing training were also observed. Notifying and recording accidents and violence also lacked precision; ensuring that these were done properly would allow track to be kept of them as well as developing a proper assessment and action plan. However, important state, city and academic initiatives towards preventing and reducing morbidity and mortality caused by accidents and violence in particular municipalities were identified.

Conclusions Taking national policy for reducing accident- and violence-related morbidity and mortality as a point of reference, then it can be seen that some advances have been made in the city of Recife; however, many shortcomings can still be seen in terms of introducing such policy.
\end{abstract}

Key Words: Health policy, accident, violence, prehospital emergency care (source: MeSH, NLM).

\section{RESUMEN}

Objetivo El objetivo de este estudio fue realizar un diagnóstico situacional de la atención prehospitalaria proporcionada por el sistema de salud de la ciudad de Recife a las víctimas de accidentes y violencia, utilizandose como referencia la 
Política Nacional de Reducción de la Mortalidad y la Morbilidad por Accidentes y Violencia.

Métodos Se aplicaron cuestionarios y se llevaron a cabo entrevistas semiestructuradas con los directores y profesionales de trece unidades hospitalarias fijas y móviles de un hospital.

Resultados Hubo predominio de la atención a niños, niñas y adolescentes y a las mujeres; se observó escasas acciones de prevención, insuficiente cobertura de atención al público, deficientes sistemas de referencia y contrarreferencia; ausencia de articulación extra-sectorial; falta de equipo básico y suministros; disponibilidad de equipo multiprofesional, pero, con poca calificación; registro y comunicación pobres sobre la violencia y los accidentes para su control, vigilancia y planificación de las acciones. Sin embargo, fueron identificadas importantes iniciativas provinciales, municipales y académicas dirigidas a la prevención y la reducción de la morbilidad por accidentes y violencia en la ciudad.

Conclusiones Tomando como un punto de referencia la Política Nacional de Reducción de la Mortalidad y la Morbilidad por Accidentes y Violencia, algunos avances y muchos defectos pueden ser vistos en términos de la introducción de esta política en la ciudad de Recife.

Palabras Claves: Política de salud, accidentes, violencia, atención prehospitalaria (fuente: DeCS, BIREME).

R ecife is located in northeastern Brazil and is considered to be one of the country's most violent state capitals. A total of 2,623 deaths resulted from accidents and violence during 2006, making this city the third worst in the country for the number of deaths resulting from external causes. This gives a rate of 173.1 such deaths per 100,000 inhabitants, this being the third most common cause of death among the population at large in Recife. (1) Regarding morbidity, 14,876 hospital stays in Recife were caused by accidents or violence in 2007 , this being the fifth most common cause of hospitalisation, with falls and road-accidents being the most common events. (2)

Brazil has public policy laying down guidelines regarding the care to be received by the victims of such incidents (i.e. national policy for reducing accident- and violence-related mortality and morbidity (PNRMAV), (3) state accident and emergency services' technical regulations (4) and national emergency care policy). (5) This outlines the main guidelines for organising the care model to meet the needs of the sectors of the population which are at greater risk of being the victims of accidents or acts of violence.

Installing and implementing PNRMAV has been posing a considerable challenge for state and municipal authorities since 2001, when Law 737/GM-MS was passed. (3) This article presents a diagnostic analysis of the care provided 
by the municipal services of the Brazilian National Health Service/SUS in the city of Recife, focusing specifically on the prehospital care provided for victims of accidents and acts of violence. The main proposal is to investigate how the installation and implementation of the PNRMAV has been being carried out in this city, with a view to identifying progress that has been made and the shortcomings that have been revealed in the course of this process.

\section{METHODOLOGY}

This study was conducted as part of a research project entitled, "Analysing national health policy regarding reducing mortality and morbidity stemming from accidents and violence" conducted by the Jorge Carelli Latin-American Center for Violence and Health Studies (CLAVES) at FIOCRUZ, in collaboration with various research centers in the cities of Rio de Janeiro, Curitiba, Manaus, Recife and the Federal District of Brasília betwen 2005 and 2006 (6).

The basic methodology adopted by this study was diagnostic analysis which consists of a comprehensive analysis for interpreting a given situation, taking the general state of infrastructure, planning and support into account for ensuring the success of any action taken (7). The study followed the principles of triangulation, a strategy which aims to interweave multiple academic points of view, techniques, strategies and methods, using both quantitative and qualitative approaches (8).

The documents used to guide the study framework were national policy for reducing accident and violence related morbidity and mortality (3), the national emergency care policy (5), administrative ruling (AR) 1864-GM/MS (9) which set up the mobile prehospital component of the national emergency care policy, AR 2072-GM/MS which set up the national emergency care management committee (10) and AR 2048-GM/MS which approved the technical regulations for state emergency care systems (3).

The research's exploratory phase involved interviewing specialists and managers; analysing these interviews, along with that of the policy documents, provided the basis for developing the research tools to be used for a better understanding of care quality. Fresh questionnaires were then applied for mapping the care network, characterising services and analysing service structure and organisation. The questionnaires were filled in by each unit's manager or a subordinate designated by such manager. Semi-structured interviews were also 
carried out with managers from this care-level covering the care provided for victims of accidents and acts of violence and compliance with PNRMAV guidelines (3) and other quality parameters included in the most important policy documents and administrative rulings.

The information from the questionnaires was typed into a database using EpiData software and submitted to critical analysis. Analysis of the information was exploratory, descriptive statistical measurements being obtained (simple and relative frequencies). The qualitative analysis looked for interaction between manifest content and inference as outlined by Bardin (11). Quantitative data and the analysis of reports and the various actors' testimony were subsequently triangulated (8).

\section{RESULTS}

All services in Recife currently attending victims of accidents and violence were included. Data for fixed prehospital care (specialised outpatient units, diagnostic and treatment services and non-hospital emergency care units) are presented first, followed by those for mobile prehospital care (ambulance service).

Fixed prehospital care

Thirteen fixed prehospital units/services in Recife attending the victims of accidents and violence were identified; ten of them fell under municipal administration and three under state administration according to how a particular institution was being managed according to the policy of decentralisation which is one of the Brazilian National Health Service's basic principles.

Analysing the activities being carried out by the care teams revealed that both municipal and state services gave priority to those related to curative care. Most of these services had a strictly medical function although five of them also provided psychological and social services. Little was being provided in terms of prevention and health promotion.

Regarding the groups most frequently attended, most patients attended at the ten units were females and young people, followed by males and the elderly at the four $24 \mathrm{hr}$ emergency services. Families (as a unit) were the group mentined least, with only one service reporting providing care for families as a whole. 
It was confirmed that ten of the services studied had physical structure complying with the required standards, such as having a reception area and a waiting room, medical records, screening for risk, social services, consulting rooms for doctors, dentists and psychologists, emergency rooms, inhaler rooms, treatment rooms, suture rooms, washing of materials, sterilisation, storage space, a pharmacy, a clinical pathology lab, a cloak room, a refectory and a morgue. Of the services studied, four had special access for ambulances and only two had a ramp for disabled people, suggesting that most health units still do not provide for this group's specific needs.

Evaluating durable and perishable material resources revealed that eleven services had the equipment recommended by AR 2048-GM/MS, (4) this being equal to the number of units equipped with the basic medications recommended for prehospital care. However, the reports provided suggested that, even when these were available and suitable, they were insufficient to meet demand. The following interview extract illustrates this.

"Here in the emergency room we have to cope with a number of problems, such as an overload of patients, the ambulance service lacks medicine and the diagnostic support equipment is inadequate, especially for patients with trauma (emergency service manager)".

Most services were working with a multiprofessional team which included a doctor, social worker, psychologist, nurse and nursing assistant. Other professionals such as dentists, biochemists, laboratory technicians and assistants and radiologists were rarely present.

As for organisation, the provision of care for the victims of accidents and violence requires the need for communication within the sector and with other sectors and is so stipulated in the PNRMAV guidelines. An attempt was made to identify the network of referral and counter-referral with which the services interact. The highest figures were for referring patients to the tutelar council $(45,4 \%)$, the special police unit for children and adolescents $(35,2 \%)$, the general hospital $(35,3 \%)$ and specialised outpatient centers $(35,3 \%)$.

The policy documents considered here require continuous training. Nevertheless, in the case of most services, further professional training in attending the victims of accidents and violence was sought out on the initiative of individual professionals and not as a matter of institutional policy, either in the state or municipal system. 
Only two of the services had protocols for dealing with the victims of accidents and violence. Only four managers of the services studied were aware of the national policy for preventing accidents and violence, suggesting that this has not been sufficiently publicised in the municipality.

The managers and health workers identified the following critical points for providing care for the victims of accidents and violence: a lack of professionals specialising in this area and the absence of an orthopaedist and surgeon for performing minor surgical procedures at the $24 \mathrm{hr}$ emergency services. These items were scored lower than five on a scale of nought to ten.

Mobile prehospital care - SAMU

Although SAMU has been part of the national emergency care policy since 2003, Recife has had this service since 2002 and it is responsible for attending emergency calls from people at risk of death, as in cases of accidents on public roads or in the home, clinical and obstetric emergencies and transporting patients to hospital to ensure that they remain alive while they are on the way.

The fire brigade has traditionally been responsible for rescuing people in life-threatening situations on public roads in and around Recife, as in several other Brazilian cities. The service was gradually turned over to SAMU and encountered some opposition. The fire brigade currently provides emergency rescue service only when, in addition to a life-threatening situation, there is also a risk of explosion, fire, the collapse of a building, or when a victim is trapped in a vehicle, or when their presence is requested by the regulation center.

Replacing the rescue service by SAMU brought about an improvement in the quality of care, since it included a doctor and a multiprofessional emergency team trained in the national programme's standards and procedures. Additionally, different types of ambulance are equipped with appropriate rescue equipment. However, the change did not signify a break between the two services, as shown by the following statement made by SAMU's director:

"There is a great deal of integration between the two services so far as trauma is concerned and there is no difficulty in providing trauma care in this city"

SAMU/Recife was called out to private homes and incidents occurring on public roads on an average of 30,293 occasions per month during 2004. From 
January to July 2005, 213,794 calls were registered, around $2 \%$ relating to accidents or violence and $98 \%$ to clinical emergencies which should give cause for reflection on the prehospital care nework's success rate in terms of providing clinical care for the population (Table 1). Of the total number of patients treated for external causes, $87 \%$ resulted from general accidents and only $13 \%$ from acts of violence (assaults and self-inflicted injuries) which is a relatively low percentage, probably because the seriousness of the latter usually resulted in death.

Table 1. Distribution of SAMU calls, Recife, 2004 and $2005^{*}$

\begin{tabular}{lcccc}
\hline \multirow{2}{*}{ Reasons for call } & \multicolumn{2}{c}{2004} & \multicolumn{3}{c}{2005} \\
\cline { 2 - 5 } & $\mathrm{N}$ & $\%$ & $\mathrm{~N}$ & $\%$ \\
\hline Assault & 670 & 0.18 & 280 & 0.13 \\
Self-inflicted Injuries & 143 & 0.04 & 66 & 0.03 \\
Road accidents & 3,447 & 0.95 & 1,541 & 0.72 \\
Falls & 1,703 & 0.47 & 852 & 0.40 \\
Other accidents & 396 & 0.11 & 185 & 0.09 \\
Other & & 98.25 & & 98.63 \\
\hline Total & 363,514 & 100.00 & 213,794 & 100.00 \\
\hline
\end{tabular}

* 2005 includes only data from the first semester.

SAMU is equipped with a total of eleven type B (basic life support) and $\mathrm{D}$ ambulances (advanced life support). It does not have any type $\mathrm{C}$ ambulances (equipped with rescue gear and used for rescue and providing prehospital care for victims of accidents in places that are difficult to access) nor does it have any type E airborne ambulances. All the ambulances are properly equipped and stocked with medicines as laid out in AR 2048 GM/ MS. (4)

AR 2048 GM/MS (4) does not provide any stipulations regarding the number of professionals necessary for each SAMU unit. During the period being studied, the service's human resources included a coordinating doctor, 28 other doctors, 17 nurses, 84 nursing assistants and 70 drivers.

Most members of the medical team and most rescue workers had received training in advanced trauma life support (ATLS). However, it has been reported that it is difficult to keep these individuals' training up to date, given a high staff turnover rate which would require continuous training. The emergency training unit was thus set up to comply with PNRMAV guidelines regarding human resource training; this unit has been following the norms established by the Ministry of Health during training courses. 
Patient records were very poorly kept. Nevertheless, data was being typed into a computer programme and used as the basis for planning action, although not being used for drawing up risk maps. Efforts are currently being made to link up health databases with those of the Transport and Urban Traffic Education and Information Department to enable these two organisations to analyse road accident data for the municipality (i.e. for the manager of a coordinating body specifically dealing with preventing accidents and violence).

The average time taken for providing the service was calculated since promptness is one of the essential requirements of mobile prehospital care services (Box 1). It can be seen that average total response time was 45 minutes. One of the regular problems making it difficult to reduce this time, apart from rush hour traffic, was the lack of available hospital beds, as the following statement confirms:

The SAMU ambulance stretcher is usually kept at referral hospitals' emergency units since emergency wards are usually overloaded with patients lying in the corridors and there is nowhere to put them when we arrive with a patient. This happens all the time (SAMU manager).

Box 1. Average duration (in minutes) of SAMU care in Recife First semester 2005

\begin{tabular}{lc}
\hline \multicolumn{1}{c}{ Average Time } & Minutes \\
\hline $\begin{array}{l}\text { Between a call being received at the Regulation Center and the SAMU } \\
\text { team's arrival at the scene of the incident }\end{array}$ & 15 \\
$\begin{array}{l}\text { At the scene of the incident from the arrival of the SAMU team at the scene } \\
\text { of the incident to its departure }\end{array}$ & 20 \\
$\begin{array}{l}\text { In transit from the scene of the incident to the referral hospital } \\
\text { Awaiting primary care from the moment of a patient's arrival at the hospital } \\
\text { unit to the point where they were attended by a qualified doctor }\end{array}$ & 10 \\
$\begin{array}{l}\text { Total response time from the receipt of the call at the Regulation Center to } \\
\text { the point when the patient was admitted to the referral hospital }\end{array}$ & 45 \\
\hline
\end{tabular}

This difficulty in finding hospital beds at the emergency units increased the total time taken for SAMU to attend patients and was rooted in other structural problems also mentioned by interviewees. Numerous calls were being made to the service by people with chronic illnesses but who were not in a critical condition, thereby taking advantage of SAMU to help them overcome the difficulties they experience in getting around the city and the difficulty in providing rapid maintenance for the ambulance fleet. 
Furthermore, the lack of communication between the various mobile prehospital units and the network of referral hospitals continues to be a source of great concern, quite apart from the inability of emergency centers to fully meet the need for beds for victims of accidents and violence (and other needs of a clinical nature). This suggests that these are chronic problems for the Brazilian National Health Service.

\section{DISCUSSION}

The provision of care for victims of accidents and violence is nowadays one of the most problematic points in the care system, since it requires specific National Health Service network restructuring and reorganisation which has hitherto been directed towards mothers and children and biomedical issues. (12) On the other hand, the national policy for reducing accident and violence related morbidity and mortality (3) in so far as one of its primary tenets is the systematisation, expansion and consolidation of prehospital care, recognises the strategic role this type of care plays in saving lives and preventing injuries.

Fixed prehospital network coverage for dealing with cases of accidents and violence in Recife is highly restricted, given an epidemiological profile whereby this was the second most common cause of death in 2004 ( 101 per 100,000 inhabitants mortality rate) and the seventh most common reason for hospitalisation. Although there were more fixed prehospital services in the municipal network (accounting for ten of the thirteen studied here), these represented only $5,9 \%$ of the prehospital network for the city as a whole.

According to national emergency care policy (5), non-hospital accident and emergency units must have a complete team and all professionals working with specific accident and emergency services should be trained at emergency education units. However, it could be seen that the situation on the ground bore little comparison to the recommended standards in terms of human resources and their levels of training.

There is an urgent need for routines and procedures to be set up for referring cases from the health sector to law-enforcement agencies, the security forces and citizens' rights groups. There is also a need for a network having good internal and external communication to ensure that action taken regarding the victims of accidents and violence is integrated, given these kinds of injuries' specific features. It would seem that some such links already exist. The high percentages of referral to the tutelar council and the special police 
units for the protection of children and adolescents are consistent with the significant figures published by services providing care for children and adolescents.

It is expected that the family health programme will also be able to serve as a point from which to observe the system and the population's general health, providing information for epistemological studies and drawing up evaluation indicators and planning all-round care in emergencies. Family health teams and community health agents in this research did not normally participate in providing care for the victims of acts of violence. This was mainly due to a lack of staff training in diagnosing such cases but also due to a fear of getting involved in a violent situation in one's own community, or through lack of awareness of the existence of a network of social support for victims of such violence and this network's inadequacy.

Difficulties were observed regarding keeping records of injuries resulting from external causes and this hindered planning, taking preventative action, monitoring and surveillance and promoting healthy environments.

Mobile prehospital care is supposed to provide immediate medical attention for victims and to refer them to fixed prehospital care centers or general hospitals. Such services, when they are well-integrated, are capable of reducing or even eliminating cases of injury and trauma resulting from accidents and acts of violence, as long as the victims receive prompt care with an adequate back-up system.

According to the Committee on Trauma of the American College of Surgeons, procedures should ideally be carried out after an interval of twenty minutes (13). As trauma patients' condition is frequently critical, care should be prompt and should aim to save lives and minimise lasting injury. The total time taken in Recife was 45 minutes, this being about average when compared to other state capitals (6). This difference was mainly due to SAMU ambulances having to drive around the city seeking empty beds in referral hospitals for victims suffering multiple traumas.

Taking the set of recommendations considered to be important by the National Policy for Reducing Accident - and Violence - Related Morbidity and Mortality as a point of reference, a number of advances and shortcomings can be seen in terms of introducing this policy in Recife. Despite the shortcomings of fixed prehospital care identified here, it would be unfair to neglect mentioning progress made in terms of mobile prehospital care, especially in relation to accidents. 
Although it is not possible to extrapolate this study's results, it provides new information probably applying to the whole prehospital network in most large Brazilian state capitals. This is extremely valuable, since these are the cities in which the highest rates for accidents and violent crime are to be found and it shows the urgent need for the country to rethink the model of care provided in such cases.

It is hoped that this diagnosis of the state of implanting PNRMAV on the ground in Recife will stimulate managers to ensure that health sector structure and organisation is more in line with the guidelines laid down by recently-adopted national policy which has still not been widely publicised •

\section{REFERENCES}

1. Brasil. Ministério da Saúde/SVS [Internet]. Departamento de Informática do SUS. Informações de Saúde. Disponble en: http://www.datasus.gov.br. Consultado Febrero del 2009.

2. Brasil. Ministério da Saúde/SE/Datasus [Internet] Sistema de Informações Hospitalares do SUSSIH/SUS. Disponible en: http://www.datasus.gov.br. Consultado Febrero del 2009.

3. Brasil. Ministério da Saúde. Política Nacional de Redução de Morbimortalidade por Acidentes e Violências. Portaria GM/MS 737, 16 de maio 2001. Diário Oficial da União, Brasília, n. 96; 2001.

4. Brasil. Ministério da Saúde. Regulamento Técnico dos Sistemas Estaduais de Urgência e Emergência. Portaria GM/MS 2048, 5 de novembro de 2002. Brasília: Editora MS. Série E. Legislação de Saúde; 2002.

5. Brasil. Ministério da Saúde. Política Nacional de Atenção às Urgências. Portaria GM/MS 1863, 29 de setembro de 2003. Brasília: Editora MS. Série E. Legislação de Saúde; 2002.

6. Minayo MCS, Deslandes SF, organizadores. Análise da Implantação do Atendimento PréHospitalar. In: Análise diagnóstica da Política Nacional de Saúde para Redução de Acidentes e Violências. Rio de Janeiro: Editora Fiocruz; 2007.

7. Lima CA. A gestão em saúde na prevenção e atenção às situações de violência. Curso à Distância Impactos da Violência na Saúde. Unidade III, Módulo 17: Diagnóstico situacional da violência. Rio de Janeiro: Editora Fiocruz; 2007.

8. Minayo MCS, Assis SG, Souza ER. Avaliação por triangulação de métodos: abordagem de programas sociais. Rio de Janeiro: Editora Fiocruz; 2005.

9. Brasil. Ministério da Saúde. Portaria GM/MS 1864, 29 de setembro de 2003. Série E. Legislação de Saúde. Brasília: Editora MS; 2002.

10. Brasil. Ministério da Saúde. Portaria GM/MS 2072, 30 de outubro de 2003. Série E. Legislação de Saúde. Brasília: Editora MS; 2002.

11. Bardin L. Análise de Conteúdo. Lisboa: Edições 70; 1979.

12. Deslandes SF, Souza ER, Minayo MCS, Costa CRBSF, Krempel M, Cavalcanti ML, et al. Diagnostic characterization of services providing care to vitims of accidents and violence in five Brasilian state capitals. Ciênc Saúde Coletiva. 2006 Apr-Jun; 11(2):385-96.

13. Pepe PE, Wyatt $\mathrm{CH}$, Bickell WH, Bailey ML, Mattox KL. The relationship between total prehospital time and outcome in hypotensive victims of penetrating injuries. Ann Emerg Med 1987 Mar; 16(3): 293-7. 